\title{
PEMETAAN PENGGUNAAN LAHAN DI WILAYAH KEPESISIRAN SEMBULANG PULAU GALANG KOTA BATAM
}

\author{
Arif Roziqin*, Oktavianto Gustin*, Sudra Irawan*, Muhammad Zainuddin Lubis*, \\ Citra Swari Henora*, Dwi Anjen Setia Wulandari* \\ *Program Studi Teknik Geomatika, Politeknik Negeri Batam, Batam, 29461 \\ E-mail: arifroziqin@polibatam.ac.id.
}

\begin{abstract}
Abstrak
Aktivitas pembangunan yang tinggi berdampak pada dinamika perubahan penggunaan lahan, termasuk di wilayah kepesisiran. Penelitian ini bertujuan untuk mengetahui penggunaan lahan di wilayah Kepesisiran Sembulang, Pulau Galang, Kota Batam. Informasi penggunaan lahan diperoleh dengan cara Interpretasi tutupan lahan pada citra penginderaan jauh dan dilanjutkan dengan survei lapangan. Survei lapangan dilakukan pada tanggal 22 - 25 Maret 2019. Survei lapangan untuk melihat pemanfaatan langsung aktivitas manusia terhadap penggunaan lahan dilakukan ke semua titik wilayah kajian. Hasil penelitian menunjukkan bahwa, penggunaan lahan di wilayah kepesisiran Sembulang, Pulau Galang, Kota Batam seperti hutan (24\%), padang rumput (14\%), permukiman (12\%), mangrove (12\%) dan lahan terbuka (33\%). Fasilitas pemerintah yang berfungsi untuk pelayanan publik juga terdapat di wilayah ini, seperti Kelurahan Sembulang dan Kecamatan Galang.
\end{abstract}

Kata Kunci: Penggunaan Lahan, Wilayah Kepesisiran, Mangrove, Kota Batam.

\begin{abstract}
High development activities have an impact on the dynamics of landuse change, including in coastal areas. This study aims to determine landuse in the Coastal Area of Sembulang, Galang Island, Batam City. The landuse information is obtained by interpreting land cover on remote sensing imagery and followed by a field survey. The field survey was conducted on March 22-25, 2019. A field survey to see the direct use of human activities on landuse was carried out at all points of the study area. The results showed that, landuse in the Sembulang coastal areas, Galang Island, Batam City such as forests (24\%), grasslands (14\%), settlements (12\%), mangroves (12\%) and bare land (33\%). Government facilities that function for public services are also available in this region, such as Sembulang Urban Village and Galang Sub-District.
\end{abstract}

Keywords: Land Use, Coastal Area, Mangrove, Batam City.

\section{Pendahuluan}

Kegiatan pariwisata merupakan berbagai macam kegiatan wisata dan didukung berbagai fasilitas serta layanan yang disediakan oleh masyarakat, pengusaha, Pemerintah, dan Pemerintah Daerah (Supriono, 2017). Sektor pariwisata merupakan salah satu sumber devisa negara yang sangat penting serta mampu memberikan lapangan kerja dan bidang usaha yang luas bagi masyarakat. Kegiatan pariwisata yang terjadi di wilayah pesisir akan mengakibatkan dinamika di Wilayah Kepesisiran (Roziqin, 2016).

Kepulauan Riau merupakan salah satu provinsi di Indonesia yang memiliki potensi pariwisata yang sangat besar (BPS Kepulauan Riau, 2019). Beberapa diantaranya memiliki kualitas dan daya tarik tinggi yang telah diandalkan sebagai sektor wisata yang potensial meliputi wisata alam hingga wisata budaya. Hal ini tentunya dapat menjadi sumber pendapatan bagi masyarakat setempat yang juga dapat membantu dalam meningkatkan devisa negara (Supriono, 2017).

Dengan kelebihan potensi sumberdaya alam di Kepulauan Riau, masih banyak potensi yang ada daerah di Kepulauan Riau yang belum dikelola secara baik khususnya di wilayah kepesisiran Sembulang, Kecamatan Galang, Kota Batam. Padahal daerah yang memiliki luas $65.834 \mathrm{~km} 2$ ini memiliki potensi alam yang cukup indah untuk dijadikan objek wisata (BPS Kota Batam, 2018).

Wilayah kepesisiran Sembulang memiliki 
pantai dengan garis pantai yang menarik dan indah untuk objek wisata. Aktivitas pemanfaatan lahan untuk kegiatan wisata dan kegiatan lainnya yang mendukung kegiatan pariwisata telah menyebabkan pemanfaatan lahan (Roziqin $d k k, 2017$ ). Pemanfaatan lahan untuk berbagai aktivitas manusia dipastikan berdampak pada dinamika dan proses kepesisiran yang sering disebut coastal process (Roziqin dkk, 2018). Atas dasar kondisi permasalahan yang telah dijelaskan sebelumnya, maka perlu dilakukan kajian mengenai penggunaan lahan di kepesisiran Sembulang, Kota Batam. Adapun tujuan penelitian ini adalah mengkaji penggunaan lahan yang ada di wilayah kepesisiran Sembulang, Kecamatan Galang, Kota Batam. Untuk mencapai tujuan penelitian yang telah ditetapkan dengan interpretasi citra Google Earth dan survei lapangan.

\section{Metode Penelitian}

\subsection{Desain Penelitian}

Metode penelitian adalah berisikan pendekatan yang digunakan dalam penelitian, populasi dan sampel penelitian, menjelaskan definisi operasional variabel beserta alat pengukuran data atau cara mengumpulkan data, dan metode analisis data. Penelitian ini dilakukan dengan memanfaatkan citra Google Earth dan survei lapangan untuk mendapatkan informasi pengguaan lahan yang disajikan dalam bentuk peta penggunaan lahan. Kajian spasial menggunakan sistem informasi geografis (Roziqin $d k k, 2018$ ). Survei lapangan juga dilakukan untuk pengamatan data ekosistem dan organisme di wilayah kepesisiran, serta karakteristik pantai langsung dari lapangan.

Hasil pengolahan data akan diinterpretasikan dalam bentuk peta yang kemudian akan dilakukan proses analisis sesuai dengan kajian yang akan diambil (Roziqin $d k k$, 2017). Penelitian ini dilakukan di wilayah kepesisiran Sembulang, Pulau Galang, Kota Batam (Gambar 1).

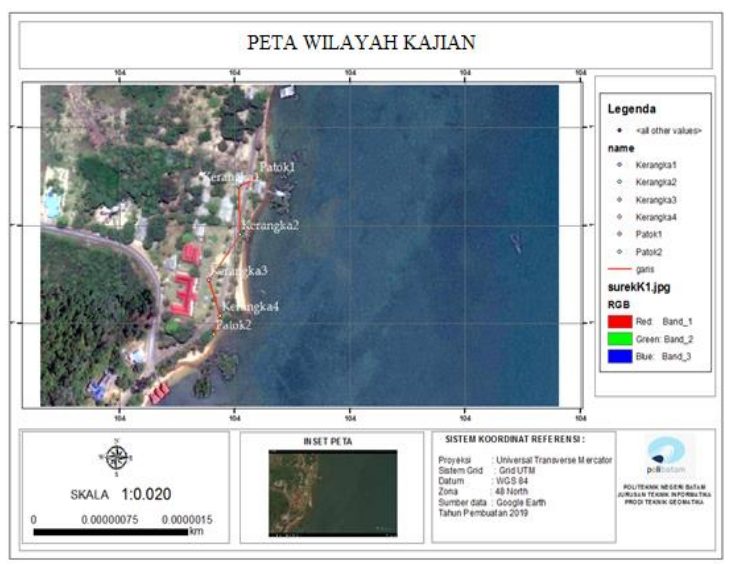

Gambar 1. Daerah Penelitian

\subsection{Alat dan Bahan}

Adapun alat yang dibutuhkan adalah sebagai berikut:

- Seperangkat Komputer.

- Perangkat Lunak Geographic Information System (GIS).

- Global Positioning System (GPS).

Adapun bahan yang dibutuhkan sebagai berikut

- Data Citra dari Google Earth Perekaman Tahun 2017.

- Shp Pulau Batam Tahun 2011 diperoleh dari Badan Pengusahaan (BP) Kawasan Batam.

- Data hasil survei lapangan tahun 2019.

\section{Hasil dan Pembahasan}

\subsection{Penggunaan Lahan di Wilayah Kepesisiran Sembulang}

Menurut Undang-undang Nomor 27 tahun 2007, wilayah pesisir adalah daerah peralihan antara ekosistem darat dan laut yang dipengaruhi oleh perubahan di darat dan laut. Sedangkan kepesisiran lebih luas lagi dan tidak hanya zona peralihan tetapi meliputi darat sampai laut sebelum zona lepas pantai (Roziqin $d k k$, 2017). Sehingga tidak ada garis batas yang nyata, yang ada hanya garis khayal wilayah pesisir yang menentukan letak atau kondisi tempat tersebut (Roziqin $d k k$, 2017). Kawasan pesisir berupa wilayah peralihan antara daratan dan perairan laut yang secara fisiologi didefinisikan sebagai wilayah antara garis pantai hingga kearah daratan yang masih dipengaruhi oleh kelandaian pantai dan dasar laut, serta dibentuk oleh endapan lempung hingga pasir yang bersifat lepas dan kadang meterinya berupa pasir (Roziqin, 2016).

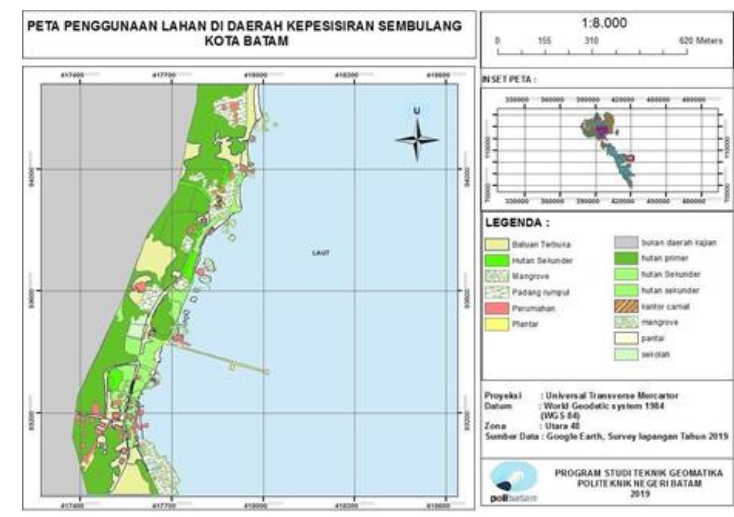

Gambar 2. Peta Penggunaan Lahan di Kepesisiran Sembulang, Kota Batam

Berdasarkan Gambar 2, adalah peta yang menggambarkan informasi sebaran penggunaan lahan yang ada di kepesisiran Sembulang, Kecamatan Galang, Kota Batam. Hasil penelitian menunjukkan bahwa penggunaan lahan 
diklasifikasikan menjadi lahan terbuka, permukiman, fasilitas perkantoran pemerintah, sekolah, hutan sekunder, hutan primer, padang rumput, ekosistem mangrove, padang rumput. Penggunaan lahan merupakan wujud nyata dari pengaruh aktivitas manusia terhadap terhadap pemanfaatan lahan. Penelitian ini menghasilkan sebuah peta penggunaan lahan.

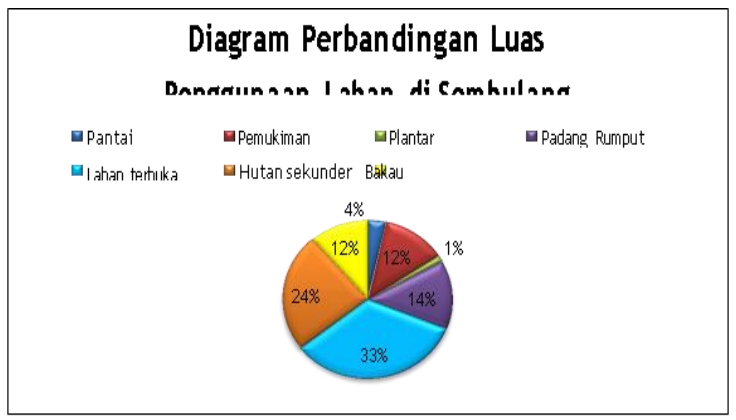

Diagram 3. Diagram Perbandingan Penggunaan Lahan di Kepesisiran Sembulang, Kota Batam

Informasi mengenai penggunaan lahan yang telah diteliti. Dari luas wilayah kajian yang telah ditentukan dapat terlihat bahwa lahan terbuka memiliki luas $33 \%$ dari keseluruhan luas, disusul oleh hutan sekunder yang memiliki luas 24\%, padang rumput $14 \%$, bakau $12 \%$, pemukiman $12 \%$, pantai $4 \%$. Perumusan strategi pengelolaan wilayah kepesisiran yang baik, dapat dimulai dengan menganalisis dari kelemahan dan kekuatan yang dimiliki oleh wilayah tersebut. Berikut beberapa kenampakan penggunaan lahan di lokasi penelitian saat survei lapangan tahun 2019, disajikan seperti pada Gambar 4.

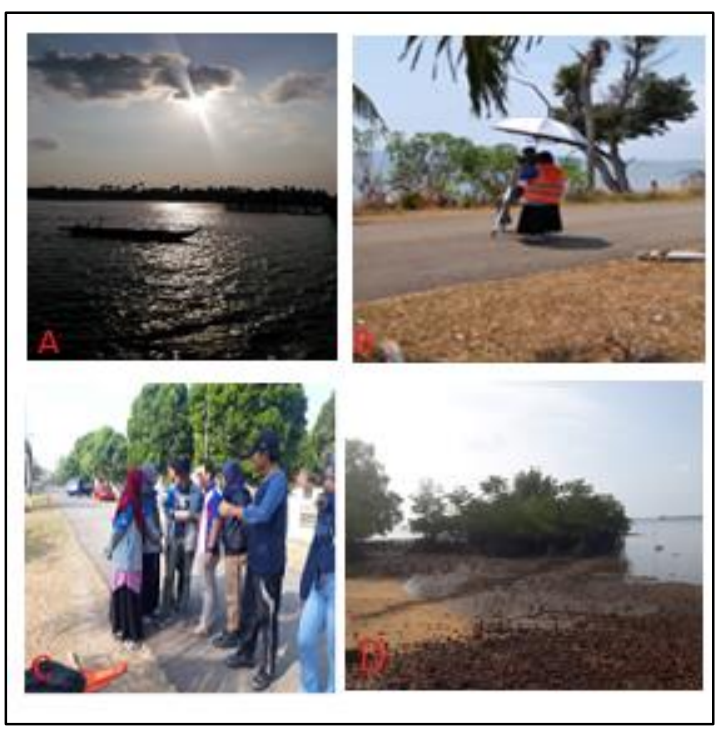

Gambar 4. Kondisi Penggunaan Lahan Kepesisiran Sembulang saat Survei Lapangan Tahun 2019
A. Saat survei lapangan di laut.
B. Saat survei lapangan di darat.
C. Pengamatan informasi penggunaan lahan di darat.
D. Ekosistem mangrove

\subsection{Peta Tipologi dan Karakteristik Pantai Di Daerah Kepesisiran Sembulang Kota Batam}

Kenampakan suatu permukaan bumi yang direpresentasikan bentuklahan atau landform disebut dengan morfologi. Secara klasifikasi morfologi dibagi menjadi dua, yaitu morfografi yang merupakan gambaran umum mengenai suatu area seperti daratan, perbukitan, pegunungan, sedangkan morfometri aspek kuantitatif dari suatu area dan biasanya dinyatakan dalam bentuk persen atau derajat. Berikut merupakan hasil pemetaan tipologi dan karakteristik pantai di wilayah kepesisiran Sembulang, Kota Batam disajikan seperti Gambar 5.

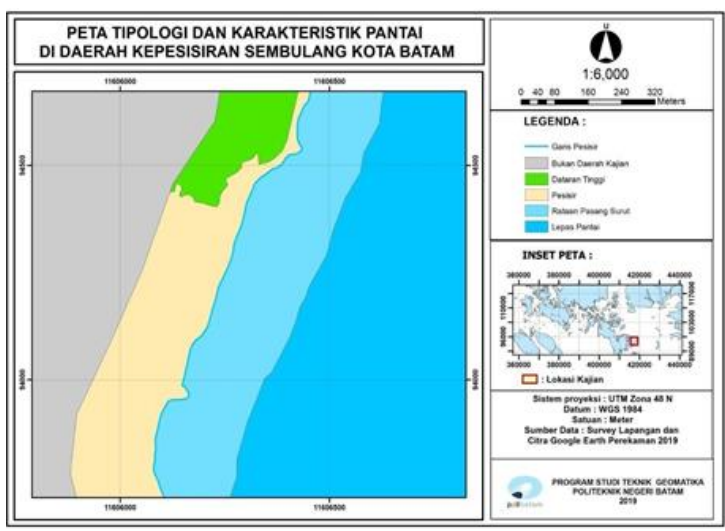

Gambar 5.Peta Tipologi Dan Karakteristik Pantai di Kepesisiran Sembulang, Kota Batam

Tipologi pantai merupakan hasil interaksi proses dinamis dari beberapa aspek geologi yang meliputi topografi, ketahanan litologi, hidrologi, aktivitas gunung api, tektonik dan proses sedimentasi. Peta tipologi dan karakteristik pantai pada penelitian ini adalah peta yang menggambarkan informasi tipologi dan karakterisitik pantai di kepesisiran Sembulang Kecamatan Galang Kota Batam.

Tipologi dan karakteristik pantai diklasifikasikan menjadi dataran tinggi, pesisir, garis pesisir, rataan pasang surut, dan lepas pantai. rataan pasang surut adalah suatu dataran pantai yang masih dipengaruhi oleh aktivitas pasang surut air laut, dengan material penyusun umumnya lempung. Rataan pasang surut di wilayah kepesisiran Sembulang merupakan habitat bagi organisme Gonggong, yang merupakan hewan khas yang ada di Kepulauan Riau. Organisme ini sudah menjadi ciri 
khas dan sering disajikan di beberapa restoran khusus makanan laut di Kepulauan Riau. Diagram tipologi dan karakteristik pantai disajikan seperti pada Gambar 6.

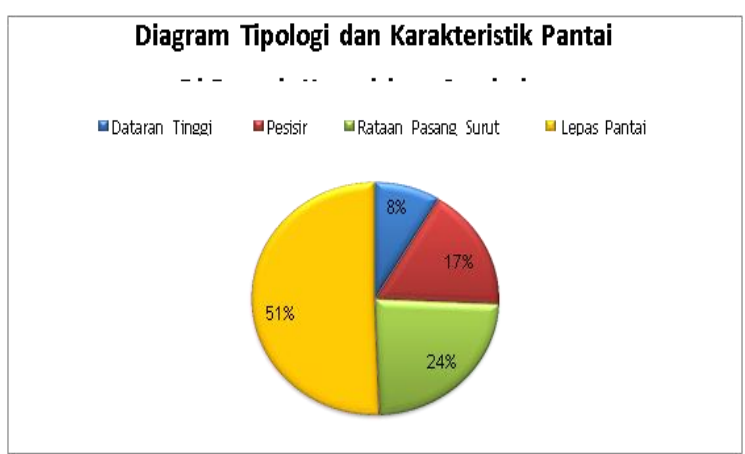

Diagram 6. Diagram Tipologi dan Karakteristik Pantai di Kepesisiran Sembulang, Kota Batam

Diagram pada Gambar 6, adalah diagram yang menunjukkan perbandingan luas dari informasi mengenai tipologi dan karakteristik pantai di daerah kepesisiran Sembulang yang telah diteliti. Dari luas wilayah kajian yang telah ditentukan dapat terlihat bahwa lepas pantai Sembulang memiliki luas 51\% dari keseluruhan luas, area rataan pasang surut memiliki luas $24 \%$, pesisir $17 \%$, dan dataran tinggi $12 \%$. Diagram dibawah adalah diagram yang menunjukkan perbandingan luas dari informasi mengenai ekosistem dan organisme di daerah kepesisiran Sembulang yang telah diteliti.

\subsection{Peta Ekosistem dan Organisme di Daerah Kepesisiran Sembulang Kota Batam}

Berikut merupakan hasil pemetaan ekosistem dan organisme di daerah kepesisiran Sembulang, Kota Batam. Rataan pasang surut adalah suatu dataran pantai yang masih dipengaruhi oleh aktivitas pasang surut air laut, dengan material penyusun umumnya lempung pesisiran. Lepas pantai merupakan area yang menunjukkan garis pasang air laut tertinggi ke daerah lepas, dapat dipetakan seperti Gambar 7.

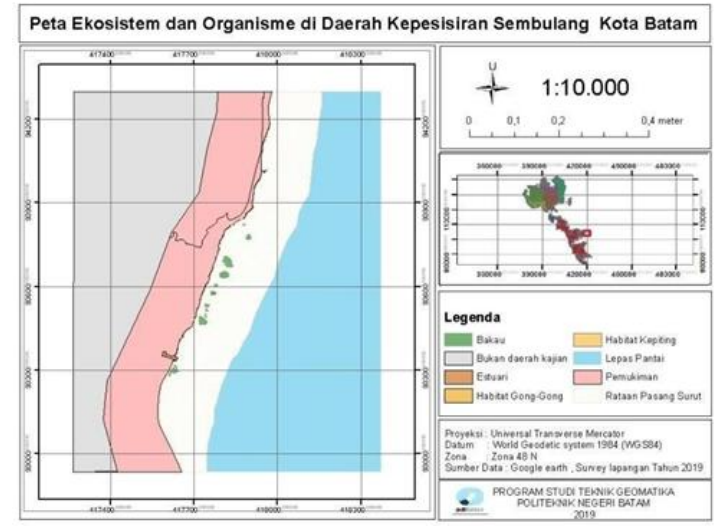

Gambar 7. Peta Ekosistem dan Organisme di Kepesisiran Sembulang, Kota Batam

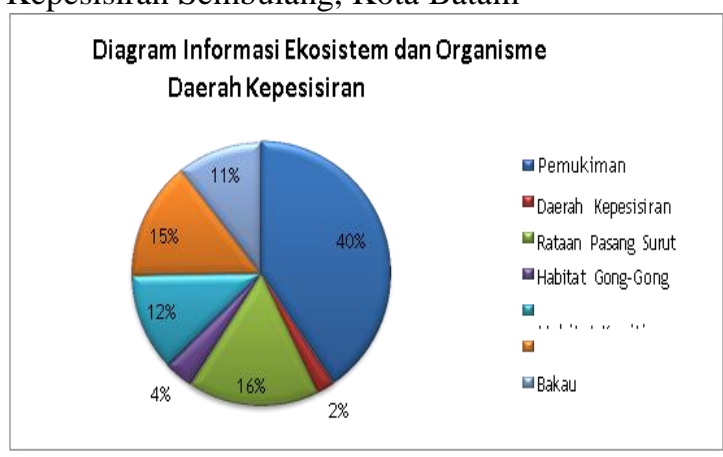

Gambar 8. Peta Ekosistem dan Organisme di Kepesisiran Sembulang, Kota Batam

Berdasarkan Gambar 8, adalah diagram yang menunjukkan perbandingan luas dari informasi mengenai ekosistem dan organisme di daerah kepesisiran Sembulang yang telah diteliti. Dari luas wilayah kajian yang telah ditentukan dapat terlihat bahwa habitat Gonggong memiliki luas $4 \%$ dari keseluruhan luas daerah kajian, habitat kepiting memiliki luas $12 \%$, bakau $11 \%$, dan zona estuari sebesar $15 \%$. Bakau merupakan ekosistem yang dapat digunakan untuk mengatasi abrasi pantai.

\section{Kesimpulan}

Atas dasar hasil penelitian dan pembahasan serta keselarasan dengan tujuan penelitian yang telah ditetapkan, maka dapat disimpulkan bahwa penggunaan lahan yang terdapat di daerah penelitian seperti hutan (24\%), padang rumput (14\%), permukiman $(12 \%)$, mangrove $(12 \%)$ dan lahan terbuka (33\%). Terdapat organisme yang khas di rataan pasang surut, yaitu Gonggong, merupakan organisme yang khas yang ada di perairan Kepulauan Riau.

\section{Ucapan Terima Kasih}

Penulis mengucapkan terima kasih kepada P3M Politeknik Negeri Batam beserta jajaran Pimpinan yang mendukung dan menciptakan iklim akademik dan penelitian yang kondusif. Penulis juga perlu ucapkan terima kasih kepada pemerintah dan aparatur sipil setempat di Kelurahan Sembulang yang telah mengizinkan lokasi Sembulang untuk menjadi lokasi kajian dalam penelitian ini. Dalam proses pengambilan data dan survei lapangan di tahun 2019, penulis perlu pengucapkan terima kasih kepada pihak yang membantu seperti Fitriyani Harahap, Farid Dzakwan Ramadhan, Geubrina Tari Bacut, Fitri Annisa, Afifah Aprilianda, Bergeria Sultra, Muhammad Dirga Tuadingo, dan Desi Laurensia Pakpahan. 


\section{Referensi}

[1] BPS Kota Batam. 2018. Kota Batam Dalam Angka.

[2] BPS Kepulauan Riau. 2018. Kepulauan Riau Dalam Angka.

[3] Kurniawan.Roni, M. H. 2011. Variasi Bulanan Gelombang Laut Indonesia . Meteorologi Dan Geofisika Vol. (13) Nomor 3, 221-232.

[4] Rahmawati Pratiwi, M. 2016. Rencana Zonasi Wiayah Pesisir. Semarang: E-Journal Universitas Diponogoro

[5] Romimoharto, K. d. 2011. Biologi Laut. Jakarta: Djambatan.

[6] Roziqin, A. 2016. Pemodelan SIG untuk Kesesuaian Lahan Permukiman Wilayah Pesisir Nongsa di Pulau Batam. Seminar Nasional Teknologi Terapan (SNTT), Yogyakarta.

[7] Roziqin, A., Gustin, O. 2017. Pemetaan Perubahan Garis Pantai Menggunakan Citra Penginderaan Jauh di Pulau Batam. Industrial Research Workshop and National Seminar (IRWNS) Politeknik Negeri Bandung.

[8] Roziqin, A., Kusumawati, N.I. 2017. Analisis Pola Permukiman Menggunakan Data Penginderaan Jauh di Pulau Batam. Industrial Research Workshop and National Seminar (IRWNS) Politeknik Negeri Bandung.

[9] Roziqin, A., Gustin, O., Syari, I.P. 2018. Landslide Distribution Using Geographic Information System in Batam Island. International Conference on Applied Engineering (ICAE).

[10]Roziqin, A., Gustin, O. 2018. Abrasion and Accretion in Batam Island. $5^{\text {th }}$ International Conference on Research, Implementation and Education of Mathematics and Sciences (ICRIEMS).

[11]Supriono. 2017. Analisis Deskripsi Potensi Pariwisata Kota Batam Dalam Rangka Menjaring Wisatawan Mancanegara. Jurnal Pariwisata Terapan Vol. (1) No. 2.

[12]UU Republik Indonesia Nomor 27 Tahun 2007 Tentang Pengelolaan Wilayah Pesisir dan Pulau-pulau Kecil. 